\title{
Correlations of Anemia, Stunting, and Sociodemographic Characteristics and Energy Among Children Aged 6-23 Months at Karangklesem Village, South Purwokerto
}

\author{
$1^{\text {st }}$ Fauziah Hanum Nur Adriyani, \\ Department of Health, Midwifery Program, \\ Harapan Bangsa University, Indonesia \\ fauziahhanum@uhb.ac.id
}

\begin{abstract}
Stunting and anemia are longstanding public health challenges which adversely affects the cognitive development and physical wellbeing of children. Anemia and stunting occurring in this key period have serious implications for individuals and societies, especially in rural areas in developing country. The aim of this study was to assess the prevalence and associated factors of stunting and anemia among 624 months old children. The methode Cross-sectional survey was conducted among 134 children aged 6-24 months, which were living at Karangklesem village, in july 2019. A multistage sampling technique was used. children were randomly selected and used systematic random sampling method to select the research participants. Data on sociodemographic, anthropometric, dietary energy, blood samples for hemoglobin were collected. Binary logistic regression model was used to identify factors associated with the outcome variables (stunting and anemia) separately, and finally multivariable logistic regression model was
\end{abstract}

\section{INTRODUCTION}

One indicator of children's health is reviewed through the nutritional status of the child. The problem of stunting and anemia is a health burden in developing countries, especially in Indonesia. Anemia and stunting are two nutritional problems that are often

\author{
$2^{\text {nd }}$ Arlyana Hikmanti \\ Department of Health, Midwifery Program, \\ Harapan Bangsa University, Indonesia \\ arlyanahikmanti@uhb.ac.id
}

used to identify independent variables of each outcomes. The result showed that $35,07 \%$ of children at Karangklesem were suffered from anemia and the malnutrition with prevalence rates of $31,34 \%$ for stunting, and $15,67 \%$ for stunting chronic. Anemia was significantly associated with malnutrition ( stunting, OR: 1.65, 95\% CI: 1.052.61. In the multivariable analyses, energy $(O R=4,18,95 \%$ CI: $2,65-6,57)$ and low family income $(O R=4,08,95 \%$ CI: $1,33-12,54)$ and anemia were factors significantly associated with stunting. less maternal education, parent's job not significantly increased the risk for infant anemia. This study revealed highlevel of stunting and anemia among children aged 6-24 months. Specific sociodemographic characteristics and energy were highly associated with infant anemia in rural areas of Karangklesem. Health education focusing on feeding practices and nutrition education could be a practical strategy for preventing anemia and malnutrition in young children.

Keywords: children, stunting, anemia, sociodemographic, energy

found in Indonesia [1]. WHO data showed that on average $36 \%$ of children in the Southeast Asia Region had greater nutritional problems than the global average of $26 \%$ with Indonesia having stunting children $37.2 \%$ higher than the regional or global average [2] and anemia prevalence above $40 \%$ is also classified as a public health problem that is 
dangerous and requires comprehensive and intervention design [3]. Indonesia needs hard efforts to reduce the incidence of stunting cases $<40 \%$ in 2025 based on WHO targets [4]. Anemia and stunting have serious implications on individuals and society in the short and long term. Nutritional deficiencies in early life lead to higher infant and child mortality, increased susceptibility to infections and diseases, impaired cognitive abilities, all of which result in long-term economic losses for individuals and

Indonesians [5][6].

Several factors that influence the incidence of anemia and stunting include problems of malnutrition, poor socioeconomic status, poor sanitation or hygiene practices, poor feeding patterns, diseases that occur in children coupled with poor utilization of health services, parental education and low health knowledge [7]. Infants and toddlers who suffer from anemia also experience stunting and vice versa. Stunting and anemia are most often caused by problems with insufficient long-term nutritional intake. Regardless of income status in Indonesia, this country bears the burden of the fifth stunted child in the world [8]. Strategy efforts are needed to deal with the problem of malnutrition comprehensively from various sectors [9]. Banyumas, Central Java Province

Indonesia, is one of the priority districts for the intervention program with the number of stunting events in 2013 of 49,138 children under five [10]. The case of nutrition problems in Banyumas in 2017 ranked 5th in the Province of Central Java in which 70 children under five suffered from nutritional problems. The number of children under five in southern Purwokerto sub-district was 1667 and has $0.5 \%$ nutritional problems in the district [11]. The purpose of this study was to explore the prevalence and relationship of stunting and anemia factors along with sociodemographic and nutritional factors.

\section{MATERIALS AND METHODS}

This is a cross sectional study approach, using quantitative analytics. The study was conducted at Karangklesem village. The population in this study were all toddlers aged 624 months at Karangklesem village consisted of 159 toddlers. Inclusion criteria in the study sample were infants and toddlers who were born at term either by Sectio Caesarea or vaginal delivery, without any congenital complications such as heart failure, infection, LBW). Exclusion criteria from this study were infants or toddlers who were sick, such as diarrhea, respiratory problems, were receiving therapeutic drugs. There were 137 toddlers who fitted the criteria, so the researchers used a total sample of 137 infants and toddlers.

Data collection and blood sampling Researchers used questionnaire instruments to collect information about sociodemographic and characteristics of respondents and families. Infant weight was measured using the standard method described by WHO [12]. Weight was measured on an electronic scale. Recumbent length was measured to the nearest $\mathrm{cm}$ on the measuring board. The results of interpretation of height measurements based on age for the stunting category are using the WHO reference standard [12]. Categories were very short if Z Score <-3 SD, short if ZScore $\leq-3$ to $<-2$ SD and normal if ZScore $\geq-2$ up to +2 . Measurement of the average energy using a food record within a period of one month was carried out by recording nutri surveys of the 
types of food consumed by infants and toddlers. The category of energy needs was fulfilled if the average energy intake was $\geq 1300$ Kcal. Anemia status measurement used was peripheral blood sampling. To measure hemoglobin levels in the fingers, a calibrated instrument was used. The category of anemia in infants aged 6-24 months was the $\mathrm{Hb}$ level < $11 \mathrm{gr} / \mathrm{dl}$.

All data analyzes were performed with SPSS version 17.0. Bivariate data analysis was performed to determine the relationship of iron adequacy with stunting events using the Fisher's Exact test with a P-Value <0.05. Multivariate analysis to determine factors related to anemia and stunting with logistic regression to determine Odd ratio (OR) dan and $95 \%$ confidence interval.

\section{RESULT}

3.1.Prevalence of Iron Deficiency Anemia in Toddlers 6-24 Months Toddler $\mathrm{Hb}$ levels vary from $<10 \mathrm{~g} /$ $\mathrm{dL}->13.8 \mathrm{~g} / \mathrm{dL}$. The distribution of under fives according to $\mathrm{Hb}$ levels was at most 11-13.8 $\mathrm{g} / \mathrm{dL}$, while the distribution was at least in the Hb level $<10 \mathrm{~g} / \mathrm{dL}$ and at Hb levels $>13.8 \mathrm{~g} / \mathrm{dL}$.

Table 1. toddlers 6-24 months according to hemoglobin level

\begin{tabular}{|c|c|c|}
\hline $\begin{array}{c}\mathrm{Hb} \\
\text { Levels } \\
\text { (g/dL) }\end{array}$ & Number & Percentage \\
\hline$<10$ & 18 & 13,43 \\
\hline $10-10,9$ & 29 & 21,64 \\
\hline $11-13,8$ & 65 & 48,50 \\
\hline$>13,8$ & 22 & 16,41 \\
\hline Number & 134 & 100 \\
\hline
\end{tabular}

Based on examination and classification of $\mathrm{Hb}$ levels on anemia and no-anemia status, there were 41 toddlers $(35.07 \%)$ of toddlers suffering from anemia with $\mathrm{Hb}$ levels $<11 \mathrm{~g} /$ $\mathrm{dL}$, and 93 toddlers without anemia $(69.40 \%)$. This situation is shown in table 2 .

Table 2. Number of children under five based on anemia

\begin{tabular}{ccc}
\hline Anemia State & Number & Percentage \\
\hline $\begin{array}{c}\text { Anemia }(\mathrm{Hb}<11 \\
\mathrm{gr} / \mathrm{dL})\end{array}$ & 47 & 35,07 \\
$\begin{array}{c}\text { No Anemia }(\mathrm{Hb}>11 \\
\mathrm{gr} / \mathrm{dL})\end{array}$ & 87 & 69,40 \\
\hline Number & 134 & 100 \\
\hline
\end{tabular}

\subsection{Prevalence of Stunting in Toddlers 6- 24 Months}

This situation varies from height / age <3SD (very short, between - <2 SD to -3SD (short), and $>$ - 2SD (normal). 2 SD while the distribution is at least in the <-3SD group (very short and between - <2 SD to -3SD. This

Table 3 Distribution of toddlers 6-24 months according to height based on age

\begin{tabular}{ccc}
\hline $\begin{array}{c}\text { nutritional status } \\
\text { (height/ age) }\end{array}$ & Number & Percentage \\
\hline $\begin{array}{c}<- \text { 3SD (chronic } \\
\text { stunting) }\end{array}$ & 21 & 15,67 \\
$-<$ 2 SD sd -3SD & 42 & 31,34 \\
(stunting), & & 52,9 \\
$\quad$ 2SD & 71 & 100 \\
\hline (normal) & & 134 \\
\hline Number & & \\
\hline
\end{tabular}




\subsection{Incidence of iron deficiency anemia based on nutritional status in infants 6-24 months}

Based on data on the incidence of iron deficiency anemia in infants to the nutritional status of infants of 6-24 months at Karangklesem Village, it was found most in infants with normal nutritional status and were not affected by anemia totaling 49 toddlers $(52.59 \%)$. Some toddlers were not anemic but had a short nutritional status of 28 toddlers $(30.11 \%)$. Cases of toddlers with anemia also occur in toddlers with normal nutrition based on TB / U of 22 toddlers $(53.66 \%)$ and experiencing anemia in short toddlers of 14 toddlers $(34.15 \%)$. The cases occurred in toddlers were very short but did not experience anemia of 16 toddlers $(17.20 \%)$. This is addressed in table 4.

We found that children who had anemia were stunted, in this case a study of the relationship between anemia and stunting had never been done. Anemic toddlers have a risk of 1.65 times to stunting. Therefore improvement efforts must include efforts to prevent and reduce interference directly (specific nutrition interventions) and efforts to prevent and reduce indirect interference (sensitive nutrition interventions).

Table 4 distribution of the incidence of iron deficiency anemia in infants 6-24 months of nutritional status

\begin{tabular}{|c|c|c|c|c|c|c|c|c|c|c|}
\hline \multirow{3}{*}{ Anemia State } & \multicolumn{6}{|c|}{ nutritional status } & \multicolumn{2}{|c|}{ number } & \multirow{3}{*}{$\begin{array}{l}\text { Odds Ratio } \\
\text { (95\% CI) }\end{array}$} & \multirow{3}{*}{$\begin{array}{c}\mathrm{P} \\
\text { Value* }^{*}\end{array}$} \\
\hline & \multicolumn{2}{|c|}{$\begin{array}{c}<-3 S D \text { (chronic } \\
\text { stunting) }\end{array}$} & \multicolumn{2}{|c|}{$\begin{array}{l}<2 \text { SD sd -3SD } \\
\text { (stunting) }\end{array}$} & \multicolumn{2}{|c|}{$\begin{array}{l}>-2 \mathrm{SD} \\
\text { (normal) }\end{array}$} & \multirow[b]{2}{*}{$\mathbf{N}$} & \multirow[b]{2}{*}{$\%$} & & \\
\hline & $\mathbf{n}$ & $\%$ & $\mathbf{n}$ & $\%$ & $\mathbf{n}$ & $\%$ & & & & \\
\hline Anemia & 5 & 12.2 & 14 & 34.1 & 22 & 53.6 & 41 & 35 & & \\
\hline no Anemia & 16 & 17.2 & 28 & 30.1 & 49 & 52.6 & 93 & 69,4 & $\begin{array}{c}1.65(1.05- \\
2.61)\end{array}$ & 0.012 \\
\hline number & 21 & 15,6 & 42 & 31,3 & 71 & 52,9 & 134 & 100 & & \\
\hline
\end{tabular}

\subsection{Nutrition, sociodemography with anemia in infants 6-24 months}

Anemia occurs in infants with an average calorie requirement in 1 month less than $1300 \mathrm{Kcal}$, were 23 toddlers or $56.1 \%$. Anemia is influenced by the body's absorption of iron which is low or nonexistent so that the caloric needs in the body are lacking in daily food composition, and the lack of variety of foods especially those containing high iron can affect the absorption or absorption of low iron in the body . Poor feeding practices also affect the amount of iron intake in food that is not enough. 
Table 5 Nutrition, sociodemographic distribution with anemia in infants 6-24 months Odds

\begin{tabular}{|c|c|c|c|c|c|c|c|c|c|}
\hline \multirow{3}{*}{\multicolumn{2}{|c|}{$\begin{array}{c}\text { Energy intake } \\
\text { sociodemography }\end{array}$}} & \multicolumn{4}{|c|}{ Anemia State } & \multirow{2}{*}{\multicolumn{2}{|c|}{ Number }} & \multirow{3}{*}{$\begin{array}{l}\text { Odds } \\
\text { Ratio } \\
(95 \% \\
\text { CI) }\end{array}$} & \multirow{3}{*}{ P Value } \\
\hline & & \multicolumn{2}{|c|}{$\begin{array}{c}\text { Anemia } \\
(\mathrm{Hb}<11 \mathrm{gr} / \mathrm{dL})\end{array}$} & \multicolumn{2}{|c|}{$\begin{array}{c}\text { No Anemia } \\
(\mathbf{H b}<11 \\
\text { gr/dL) }\end{array}$} & & & & \\
\hline & & $\mathbf{n}$ & $\%$ & $\mathrm{n}$ & $\%$ & $\mathrm{n}$ & $\%$ & & \\
\hline \multirow{2}{*}{$\begin{array}{c}\text { Energy } \\
\text { intake }\end{array}$} & $\begin{array}{l}\text { Good: Energy } \geq \\
1300 \mathrm{Kkal}\end{array}$ & 18 & 43.9 & 61 & $\begin{array}{c}65.5 \\
9\end{array}$ & 79 & 58.96 & \multirow{2}{*}{$\begin{array}{l}4.18 \\
(2.65- \\
6.57)\end{array}$} & \multirow{2}{*}{0.032} \\
\hline & $\begin{array}{l}\text { Poor: Energy< } \\
1300 \text { Kkal }\end{array}$ & 23 & 56.1 & 32 & $\begin{array}{c}34.4 \\
1\end{array}$ & 55 & 41.04 & & \\
\hline \multirow{4}{*}{$\begin{array}{l}\text { Parental } \\
\text { education }\end{array}$} & $\begin{array}{l}\text { Elementary } \\
\text { school }\end{array}$ & 14 & 34.15 & 8 & 8.6 & 22 & 16.42 & \multirow{4}{*}{$\begin{array}{l}0.36( \\
0.13- \\
0.90)\end{array}$} & \multirow{4}{*}{0.43} \\
\hline & Middle School & 9 & 21.95 & 29 & $\begin{array}{c}31.1 \\
8\end{array}$ & 38 & 28.36 & & \\
\hline & $\begin{array}{l}\text { High school, } \\
\text { vocational } \\
\text { school, MA }\end{array}$ & 11 & 26.83 & 32 & $\begin{array}{c}34.4 \\
1\end{array}$ & 43 & 32.09 & & \\
\hline & College & 7 & 17.07 & 24 & $\begin{array}{c}25.8 \\
1\end{array}$ & 31 & 23.13 & & \\
\hline \multirow{4}{*}{ Occupation } & $\begin{array}{l}\text { Laborer / farmer } \\
\text { / }\end{array}$ & 17 & 41.46 & 31 & $\begin{array}{c}33.3 \\
3\end{array}$ & 48 & 35.82 & \multirow{4}{*}{$\begin{array}{l}0.43( \\
0.18- \\
1.02)\end{array}$} & \multirow{4}{*}{0.58} \\
\hline & Street vendors & 8 & 19.51 & 28 & $\begin{array}{c}30.1 \\
1\end{array}$ & 36 & 26.87 & & \\
\hline & $\begin{array}{l}\text { Civil servants / } \\
\text { BUMN }\end{array}$ & 6 & 14.63 & 22 & $\begin{array}{c}23.6 \\
6\end{array}$ & 28 & 20.89 & & \\
\hline & Private & 10 & 24.39 & 12 & 12.9 & 22 & 16.41 & & \\
\hline \multirow{3}{*}{ income } & High & 23 & 56.1 & 65 & $\begin{array}{c}69.8 \\
9\end{array}$ & 88 & 65.67 & \multirow{2}{*}{$\begin{array}{c}4.08 \\
(1.33- \\
12.54)\end{array}$} & \multirow{2}{*}{0.015} \\
\hline & Low & 18 & 43.9 & 28 & $\begin{array}{c}30.1 \\
1\end{array}$ & 46 & 34.32 & & \\
\hline & Number & 41 & 30.6 & 93 & 69.4 & 134 & 100 & & \\
\hline
\end{tabular}




\subsection{Description of nutrition, sociodemography with the incidence of stunting in infants 6-24 months}

The incidence of stunting occurs in toddlers with an average calorie requirement in 1 month less than $1300 \mathrm{Kcal}$ which is a number of 27 toddlers or $64.29 \%$

Poor feeding practices also affect the amount of iron intake in food that is not enough.

Table 6 Nutrition, sociodemographic distribution with nutritional status in infants 6-24 months

\begin{tabular}{|c|c|c|c|c|c|c|c|c|c|c|}
\hline \multirow{3}{*}{\multicolumn{2}{|c|}{$\begin{array}{c}\text { Energy intake } \\
\text { sociodemography }\end{array}$}} & \multicolumn{4}{|c|}{$\begin{array}{c}\text { Energy intake } \\
\text { sociodemography }\end{array}$} & & & \multirow{2}{*}{\multicolumn{2}{|c|}{ Number }} & \multirow{3}{*}{ P Value } \\
\hline & & \multicolumn{2}{|c|}{$\begin{array}{l}<- \text { 3SD (chronic } \\
\text { stunting) }\end{array}$} & \multicolumn{2}{|c|}{$\begin{array}{c}-<2 \text { SD sd -3SD } \\
\text { (stunting) }\end{array}$} & \multicolumn{2}{|c|}{$>$ - 2SD (normal) } & & & \\
\hline & & & $\%$ & $\mathbf{n}$ & $\%$ & $\mathbf{n}$ & $\%$ & $\mathbf{n}$ & $\%$ & \\
\hline & Energy intake & & & & & & & & & \\
\hline & & 9 & 42.86 & 15 & 35.71 & 55 & 77.46 & 79 & 58.96 & \\
\hline \multicolumn{11}{|l|}{ Energy intake } \\
\hline & & 12 & 57.14 & 27 & 64.29 & 16 & 22.54 & 55 & 41.04 & \\
\hline & & & & & & & & & & 0.015 \\
\hline \multirow[t]{5}{*}{$\begin{array}{c}\text { Parental } \\
\text { education }\end{array}$} & $\begin{array}{l}\text { Parental } \\
\text { education }\end{array}$ & 7 & 33.33 & 9 & 21.43 & 6 & 8.45 & 22 & 16.42 & \\
\hline & & 4 & 19.05 & 13 & 30.95 & 21 & 29.58 & 38 & 28.36 & \\
\hline & & 6 & 28.57 & 11 & 26.19 & 26 & 36.62 & 43 & 32.09 & \\
\hline & & 4 & 19.05 & 9 & 21.43 & 18 & 25.35 & 31 & 23.13 & \\
\hline & & & & & & & & & & 0,021 \\
\hline \multirow[t]{6}{*}{ Occupation } & Occupation & & & & & & & & & \\
\hline & & 6 & 28.57 & 17 & 40.48 & 25 & 35.21 & 48 & 35.82 & \\
\hline & & 3 & 14.29 & 9 & 21.43 & 24 & 33.8 & 36 & 26.87 & \\
\hline & & 9 & 42.86 & 4 & 9.52 & 15 & 21.13 & 28 & 20.89 & \\
\hline & & 3 & 14.29 & 12 & 28.57 & 7 & 9.86 & 22 & 16.41 & \\
\hline & & & & & & & & & & 0,712 \\
\hline \multirow[t]{3}{*}{ income } & income & 9 & 42.86 & 18 & 42.86 & 61 & 85.92 & 88 & 65.67 & \\
\hline & & 12 & 57.14 & 24 & 57.14 & 10 & 14.08 & 46 & 34.32 & 0,023 \\
\hline & number & 21 & 15.67 & 42 & 31.34 & 71 & 52.99 & 134 & 100 & \\
\hline
\end{tabular}




\section{DISCUSSION}

Anemia and stunting are still major problems at Karangklesem Village. Some characteristics in terms of socio-demography and family nutrition affect some of the most cases in anemia and stunting one of the related factors are energy intake and family income factors. Toddler energy intake is influenced by many things with one of them was the income factor. The poverty rate in Indonesia until March 2019 was still large $(9.5 \%)$ [13]. here were 41 toddlers $(35.07 \%)$ toddlers suffering from anemia at Karangklesem village. Research in developing countries suggests that babies born to mothers suffering from anemia are likely to suffer from nutritional anemia, have low birth weight, be premature and increase mortality [14]. Feeding practices also affect the amount of iron intake in food that is not enough. The provision of food to fulfill nutrition every month for toddlers in the village is also lacking (41.04\%). Energy intake is used for the process of growth and development of infants in the golden period. Education and family income are sociodemographic factors associated with anemia in infants. This finding can be easily recognized because of the behavior of improving children's health, improper feeding, hygiene, and utilization of health services, often practiced less optimally among people in Indonesia [15][16]. The bias in this study is that the researcher did not conduct an examination of zinc and vitamin A levels, where the micronutrients can also affect the level of anemia in the body [17]. The next bias is that we do not classify age and sex for stunting status. Existing literature shows that stunting occurs most frequently over a period of 12 to 23 months of age [15][18]. This is because it takes more time to manifest than anemia which requires shorter time. The odds of anemia are higher in boys than girls the risk of anemia and stunting is higher in boys [19]. In general, children under 2 years bear a higher burden of anemia and stunting, especially in developing countries [20].

\section{CONCLUSION \\ The conclusion is that there was} relationship between the factors that influence the incidence of anemia and stunting at Karangklesem, Banyumas. The influencing factors include energy intake, education and income. Health education programs that focus on breastfeeding and complementary feeding practices can be carried out specifically. These findings suggest the urgent need for more effective infant nutrition policies and comprehensive programs that include mothers and infants, the provision of child health care and nutrition education, as well as the need to pay more attention to improving baby's health. Strengthen the comprehensive community on the issue of health / nutrition interventions.

\section{REFERENCES}

[1] R. Data center and information of Ministry Of Health, "INFODATIN," Indonesia.

[2] "World Health Organization, World Health Organization in South-East Asia," SEARO, 2017.

[3] W. H. Organization, "Iron deficiency anaemia: assessment, prevention and control: a guide for programme managers. World Health Organization, 2001."

[4] "WHO | Global targets 2025: Poster," WHO, 2015.

[5] "STUNTING AND THE FUTURE OF INDONESIA." 
[6] A. Gupta, "Nutritional anemia in preschool children," Nutr. Anemia Presch. Child., no. 2008, pp. 1-233, 2017.

[7] H. Torlesse, A. A. Cronin, S. K. Sebayang, and R. Nandy, "Determinants of stunting in Indonesian children: Evidence from a cross-sectional survey indicate a prominent role for the water, sanitation and hygiene sector in stunting reduction," BMC Public

Health, vol. 16, no. 1, Jul. 2016.

[8] U.-N. Y. UNICEF and undefined 2013, "Improving child nutrition: the achievable imperative for global progress."

[9] S. H. Mohammed, B. Larijani, and A. Esmaillzadeh, "Concurrent anemia and stunting in young children: Prevalence, dietary and non-dietary associated factors," Nutr. J., vol. 18, no. 1, Feb. 2019. [10] "(No Title)."

[11] D. K. K. Banyumas, "KATA PENGANTAR."

[12] et al de Onis M, Garza C, Onyango AW, "WHO Child Growth Standards," Acta Paediatr., vol. 95, no. 450, p. 106, 2006. [13] Badan Pusat Statistik, "Presentase Penduduk Miskin di Indonesia," vol. 75, p. 2019, 2019.

[14] E. S. Souganidis et al., "Relationship of maternal knowledge of anemia with maternal and child anemia and healthrelated behaviors targeted at anemia among families in Indonesia," Matern. Child Health J., vol. 16, no. 9, pp. 1913-1925, Dec. 2012.

[15] C. G. Victora, M. De Onis, P. C. Hallal, M. Blössner, and R. Shrimpton, "Worldwide timing of growth faltering: Revisiting implications for interventions," Pediatrics, vol. 125, no. 3, Mar. 2010.
[16] World Health Organisation, "Essential Nutrition Actions.," World Heal. Organ., p. 144, 2013.

[17] S. Lynch, R. Stoltzfus, and R. Rawat, "Critical Review of Strategies to Prevent and Control Iron Deficiency in Children," Food Nutr. Bull., vol. 28, no. 4_suppl4, pp. S610-S620, Dec. 2007.

[18] G. Danaei et al., "Risk Factors for Childhood Stunting in 137 Developing Countries: A Comparative Risk Assessment Analysis at Global, Regional, and Country Levels," PLoS Med., vol. 13, no. 11, Nov. 2016.

[19] B. J. Akombi, K. E. Agho, J. J. Hall, N. Wali, A. M. N. Renzaho, and D. Merom, "Stunting, wasting and underweight in Sub-Saharan Africa: A systematic review," International Journal of Environmental Research and Public Health, vol. 14, no. 8. MDPI AG, 2017. L. C. Smith and L. Haddad, "Reducing Child Undernutrition: Past Drivers and Priorities for the PostMDG Era," World Dev., vol. 68, no.

1, pp. 180-204, Apr. 2015. 